Dossiê: Narrativas Sagradas e Linguagens Religiosas - Editorial (․) (1)

\title{
Linguagens religiosas e Narrativas sagradas
}

Religious languages and Sacred narratives

Johan Konings*

O racionalismo da primeira e da segunda modernidade teve dificuldade para, no templo do saber, dedicar um lugar às narrativas sagradas e à linguagem religiosa. As narrativas sagradas foram declaradas mitos, a linguagem religiosa projeção. Mais grave que isso: foram banidas da ciência séria. Contudo, sob a influência do romantismo no século XIX e, sobretudo, da fenomenologia do século $\mathrm{XX}$, readquiriram o status de legítimas expressões humanas.

Ironicamente, a liberdade religiosa, originalmente propugnada para pôr fim ao catolicismo de Estado nos países herdeiros da cristandade medieval, abriu a porta à valorização positiva da multiplicidade das expressões religiosas e ao pensamento simbólico, característico da linguagem dos mitos. E a religião cristã, por sua vez, já não considerada como poder ameaçador, recebeu um lugar no universo das Ciências da Religião - certamente, um lugar compartilhado com quaisquer outras expressões religiosas e teológicas. Não somente a psicologia e a sociologia, mas também diversos setores que tradicionalmente são abrigados na teologia, reconhecem essa "parceria" do diálogo do cristianismo com as outras expressões religiosas. A exegese bíblica, por exemplo, teve de reconhecer que a linguagem do cristianismo é a mesma das tradições religiosas de Israel e de outras

Editorial recebido em 06 de junho de 2016 e aprovado em 10 de junho de 2016.

* Doutor em Teologia pela Universidade Católica de Lovaina (Leuven/Bélgica), e professor de Teologia Bíblica da FAJE. País de origem: Bélgica. E mail: koningsj5@gmail.com

Horizonte, Belo Horizonte, v. 14, n. 42, p. 236-239, abr./jun. 2016 - ISSN 2175-5841 
daquele tempo. Já se tornou comum se ouvir que a única novidade do cristianismo é... Jesus Cristo.

E aí é preciso estabelecer clara distinção entre linguagem religiosa e narrativa sagrada. A linguagem diz respeito à forma e a narrativa, ao conteúdo. Sei que muitos linguistas e pesquisadores vão, no extremo, recusar essa distinção; mas, seguindo a boa tradição aristotélica, eu a mantenho. Uma coisa são as formas de expressão religiosa, que podem eventualmente incluir temas como nascimento virginal e arrebatamento ao céu. Outra coisa são os dados factuais envolvidos na narrativa sagrada, por exemplo, que um homem do povo, crucificado por razões não totalmente esclarecidas, acaba sendo considerado o messias (in)esperado, ao qual, então, a linguagem religiosa atribui a esperança de uma volta gloriosa. No meio de tudo isso, pode-se vislumbrar ou crer que exista algo que escapa às expressões da linguagem religiosa e das narrativas mitológicas, conhecidas pelo estudo comparativo das religiões.

Por outro lado, as formas mitológicas podem se tornar inseparáveis do núcleo irredutível e "revelador" que elas trazem à fala. A tentativa de desmitologização do cristianismo mostrou que separar o conteúdo revelador de sua forma mítico-religiosa não é tarefa fácil de ser executada. Será que vale a pena trocar a mitologia antiga, respaldada por uma legião de textos veterotestamentários, por uma mitologia de fórmulas existencialistas ou sociopolíticas? Não será melhor conservar o veículo original daquilo em que se crê (e que é diferente daquilo que se crê de modo meramente nocional)? A mensagem não se confunde com o que a linguagem objetivamente diz. Configura-se como o efeito que a linguagem produz.

Assim estamos na virada que leva do historicismo à consciência semióticolinguística. As narrativas sagradas não devem ser "compreendidas" segundo seu valor ou conteúdo historiográfico, mas segundo a comunicação linguística que elas efetuam no receptor (leitor, ouvinte ou meramente "influenciado" por vias não 
rastreadas). Não a verificação historiográfica (que também tem seu papel), mas a revelação semiótica constitui o cerne da atenção que dedicamos aos "textos" (escritos ou não) das narrativas sagradas. Não o historiográfico que eles nos contam, mas o sagrado que eles nos revelam.

Mas esse sagrado pode estar "encarnado" - o termo é escolhido conscientemente - em algo ou alguém que tenha registro historiográfico. Então, a história "registrável” (como história, sempre interpretada, e não como mero dado físico) integra de modo inseparável a narração sagrada. E as tentativas de dissolver o historiográfico da linguagem religiosa que o veicula terminam normalmente em jogar fora a criança com a água em que foi lavada. Não sobra nada.

A narrativa sagrada tem de ser reconhecida e lida ou ouvida como tal, não como história profana ou informação histórica. Ela é falada numa linguagem sui generis, a linguagem religiosa. Como toda linguagem, ela produz seu efeito próprio e específico se entendida, decodificada, segundo o código semiótico que é seu. Para que isso seja possível, numa sociedade em que muitas linguagens se cruzam, é útil que exista quem possa acompanhar ou avaliar essa decodificação de modo científico, com conhecimento das coisas implicadas nesse código: linguagem simbólica, referências históricas, conceitos antropológicos de tempos idos, sistemas religiosos com suas implicações socioculturais...

Muitas vezes, esse acompanhamento é exercido pela própria tradição em que a narrativa religiosa navega. A tradição é por assim dizer o nicho ecológico da narrativa sagrada. Acontece, porém, em nosso mundo atual, que esse nicho ecológico acaba sendo perturbado, destruído até, como tantos outros. E, não em última instância, por interesses de rapina. A vulgarização comercial tanto da linguagem religiosa como das próprias narrativas sagradas produz uma poluição comparável à que sufoca o ambiente bioecológico. É tarefa das Ciências da Religião e das respectivas teologias de cada religião ter consciência disso e proteger o campo 
de sua atenção, com o mesmo respeito e solicitude que um médico dedica à saúde física ou o linguista à linguagem.

A intenção própria das Ciências da Religião e das diversas teologias deve ser não a destruição, mas o "cuidado" da experiência do sagrado e da expressão religiosa que a leva à fala. 